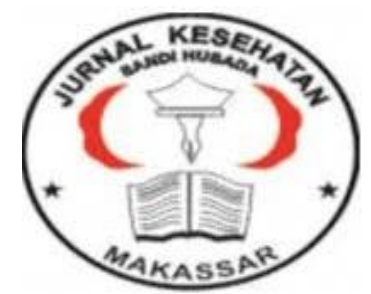

Jurnal Ilmiah Kesehatan Sandi Husada

hhttps://akper-sandikarsa.e-journal.id/JIKSH

Volume 9, Nomor 2, Desember 2020, pp 1029-1036

p-ISSN: 2354-6093 dan e-ISSN: 2654-4563

DOI: $10.35816 /$ jiskh.v10i2.458

\title{
Aspirin Dosis Rendah untuk Mencegah Preeklamsia pada Kehamilan
}

Low-Dose Aspirin to Prevent Preeclampsia in Pregnancy

\section{Aulia Berliana}

Program Studi Pendidikan Dokter, Fakultas Kedokteran Universitas Lampung

\section{Artikel info}

Artikel history:

Received; Agustus 2020

Revised: September 2020

Accepted; Oktober 2020

\begin{abstract}
.
Background. to date, an effective screening algorithm for the identification of women at risk of developing preeclampsia does not yet exist, so prevention of preeclampsia is an important component of prenatal care. Meanwhile, giving low-dose aspirin to pregnant women is thought to prevent preeclampsia in pregnancy. The aim of this literature review is to determine the effect of aspirin therapy to prevent preeclampsia in pregnancy. Method. This study is a literature review, with the literature used involving as many as 23 the results literature. Several studies have shown that the effect of low-dose aspirin therapy can significantly reduce the development of preeclampsia, reduce the incidence of preterm birth and small for gestational age significantly. Conclusion. Treatment with low-dose aspirin in women at high risk for preeclampsia resulted in a lower incidence compared with placebo
\end{abstract}

\begin{abstract}
Abstrak.
Latar belakang; Hingga saat ini, algoritma skrining yang efektif untuk identifikasi wanita yang berisiko mengalami preeklamsia masih belum ada, sehingga pencegahan preeklamsia merupakan komponen penting dari perawatan prenatal. Sementara itu, pemberian aspirin dosis rendah pada ibu hamil diduga dapat mencegah preeklamsia pada kehamilan Sehingga tujuan dari literature review ini adalah untuk mengetahui efek terapi aspirin untuk mencegah preeklamsia pada kehamilan. Metode. Studi ini merupakan literature review, dengan sumber pustaka yang digunakan melibatkan sebanyak 23 pustaka Hasil. Beberapa penelitian menunjukkan efek terapi aspirin dosis rendah dapat menurunkan perkembangan preeklamsia, mengurangi kejadian kelahiran prematur dan kelahiran bayi kecil untuk usia kehamilan (small for gestational age) secara signifikan. Kesimpulan. Pengobatan dengan aspirin dosis rendah pada wanita dengan risiko tinggi untuk preeklamsia menghasilkan insiden yang lebih rendah dibandingkan dengan plasebo.
\end{abstract}

Keywords:

Aspirin;

Preeclampsia;

Pregnancy;
Coresponden author:

Email: auliaberliana1987@gmail.com

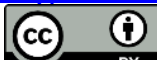

artikel dengan akses terbuka dibawah lisensi CC BY -4.0 


\section{Pendahuluan}

Kehamilan merupakan peristiwa penting yang mengarah pada perubahan signifikan dalam fisiologi ibu. Kehamilan yang berhasil memerlukan keterlibatan serangkaian proses mulai dari pembuahan hingga pembentukan hubungan plasenta dan vaskular ibu dengan janin dalam urutan yang benar. Plasentasi yang memadai merupakan salah satu prasyarat untuk menjaga kesehatan kehamilan yang normal (Mendes et al., 2019). Sementara itu, preeklamsia merupakan salah satu komplikasi hingga 8\% kehamilan dan merupakan kontributor utama kematian dan morbiditas ibu. Satu-satunya solusi yang efektif adalah persalinan, yang menyebabkan morbiditas dan mortalitas neonatal yang signifikan jika dilakukan secara prematur, terutama jika penyakit tersebut terjadi pada awal kehamilan (Odibo et al., 2015).

Secara total, preeklamsia dan komplikasi terkait menyumbang 63.000 kematian ibu di seluruh dunia setiap tahun (12\% dari semua kematian ibu). Etiologi preeklamsia masih belum diketahui, meskipun disfungsi plasenta, yang disebabkan oleh kelainan perkembangan plasenta dini, menjadi pusat dari proses penyakit ini. Penyakit plasenta dini diikuti berbulan-bulan kemudian oleh manifestasi klinis dari preeklamsia, yang mencerminkan disfungsi endotel yang meluas, mengakibatkan vasokonstriksi, end-organ iskemia dan peningkatan permeabilitas vaskular (Villa et al., 2013). Preeklamsia pada kehamilan dapat terjadi baik pada awal usia kehamilan, yaitu pada usia kehamilan $<34$ minggu maupun di akhir usia kehamilan yaitu >34 minggu (Anto et al., 2018; Khairunnisa, 2020).

Preeklamsia ditandai dengan onset baru hipertensi pada paruh kedua kehamilan, seringkali dengan tekanan darah lebih dari 140/90 $\mathrm{mmHg}$ dan proteinuria yang terjadi bersamaan. Komplikasi sistem multiorgan dapat terjadi seperti gagal ginjal, peningkatan enzim hati dan trombosit rendah (sindrom HELLP), edema, hemolisis, dan perkembangan kejang eklampsia (Amaral et al., 2017). Beberapa faktor risiko preeklamsia antara lain termasuk kehamilan pada usia ibu yang ekstrem (remaja dan wanita yang lebih tua dari 40 tahun), obesitas, hipertensi yang sudah ada sebelumnya, diagnosis preeklamsia pada kehamilan sebelumnya, diabetes atau penyakit ginjal, nuliparitas, kehamilan ganda, dan autoimun yang sudah ada sebelumnya seperti sindrom antibodi antifosfolipid dan lupus eritematosus sistemik (Grotegut, 2016). Namun, tidak semua wanita dengan faktor risiko ini mengalami preeklamsia, dan kondisi ini dapat terjadi pada wanita yang tidak memiliki faktor risiko, sehingga skrining dan pencegahan menjadi lebih perlu (Fantasia, 2018). Beberapa penelitian telah dilakukan terkait mekanisme skrining yang berbeda untuk mengidentifikasi wanita yang berisiko mengalami preeklamsia, termasuk penanda serum ibu dan temuan ultrasonografi trimester pertama (termasuk aliran dan resistensi Doppler arteri uterina), tetapi tes skrining tambahan ini tidak menghasilkan prediksi akurat dari preeklamsia. Sehingga sampai saat ini, algoritma skrining yang efektif untuk identifikasi wanita yang berisiko mengalami preeklamsia masih belum ada (Fantasia, 2018; Halscott et al., 2014).

Sementara penyebab preeklamsia masih belum banyak diketahui, pencegahan dengan aspirin dosis rendah (low dose aspirin/ LDA) di antara wanita berisiko tinggi telah dieksplorasi selama lebih dari 30 tahun. Secara khusus, LDA telah diteorikan untuk mengurangi kejadian preeklamsia, kelahiran prematur. kecil untuk bayi usia kehamilan, dan kematian perinatal. Pada tahun 2013, American College of Obstetricians and Gynecologists (ACOG) merekomendasikan LDA untuk wanita dengan riwayat preeklamsia onset dini dan persalinan prematur sebelum kehamilan 34 minggu atau preeklamsia di lebih dari satu kehamilan sebelumnya (Dixon et al., 2017). Sebagai modulator fungsi 
platelet dan inflamasi, aspirin yang diberikan dalam dosis rendah (60 sampai $150 \mathrm{mg}$ ) telah dipelajari sebagai target potensial untuk pencegahan preeklamsia dan hambatan pertumbuhan janin. Dalam dosis rendah, aspirin secara selektif menurunkan tromboksan A2 (mediator vasokonstriksi dan agregasi trombosit) tanpa mempengaruhi kadar prostasiklin secara signifikan (yang memiliki efek relaksasi otot polos) dan juga menghambat agregasi platelet (Moore et al., 2015). Adanya potensi efek samping preeklamsia untuk wanita dan bayi baru lahir, pencegahan preeklamsia terutama pada wanita dengan risiko merupakan komponen penting dari perawatan prenatal, dan aspirin diketahui memiliki efek yang potensial untuk mencegah preeklamsia pada kehamilan. Oleh karena itu, literature review ini bertujuan untuk mengetahui efek aspirin untuk pencegahan preeklamsia pada kehamilan, sehingga dapat memberikan informasi yang bermanfaat bagi masyarakat.

\section{Metode}

Metode penelitian ini menggunakan studi literature review, dengan peneliti yang berperan mencari dan menggabungkan inti sari serta menganalisis fakta dari sumber ilmiah yang sesuai kriteria valid dan akurat. Literature review menyajikan ringkasan berupa publikasi paling relevan kemudian membandingkan hasil yang disajikan dalam makalah. Penelusuran sumber pustaka dalam artikel ini melalui database PubMed dan Google Scholar. Sumber pustaka yang digunakan dalam penyusunan melibatkan sebanyak 23 pustaka. Kata kunci yang digunakan dalam penelusuran antara lain 'preeclampsia, aspirin dan mechanism', serta tahun penerbitan sumber yang didapatkan adalah antara tahun 2009-2019. Pemilihan artikel sumber pustaka dilakukan dengan melakukan peninjauan pada judul, abstrak dan hasil yang membahas tentang efek aspirin untuk mencegah preeklamsia pada kehamilan. Hasil studi literatur ini berupa publikasi yang relevan.

\section{Hasil Dan Pembahasan}

Penelitian oleh Rolnik et al (2017) membandingkan aspirin dengan dosis 150 mg per hari dengan plasebo yang diberikan dari usia kehamilan 11 hingga 14 minggu hingga 36 minggu kehamilan pada wanita dengan kehamilan tunggal yang berisiko tinggi mengalami preeklamsia prematur. Preeklamsia terjadi pada 13 peserta $(1,6 \%)$ pada kelompok aspirin, dibandingkan dengan $35(4,3 \%)$ pada kelompok plasebo (odds ratio (OR) pada kelompok aspirin 0,38; 95\% CI 0,20 hingga 0,74; $\mathrm{P}=0,004$ ). Pengobatan dengan aspirin dosis rendah pada wanita dengan risiko tinggi untuk preeklamsia menghasilkan insiden yang lebih rendah dibandingkan dengan plasebo (Rolnik et al., 2017).

Penelitian lain oleh Androkopolou et al (2018) pada 2.543 wanita, sebanyak 1262 (49,6\%) menerima aspirin dosis rendah dan 1281 wanita $(50,4 \%)$ mendapatkan plasebo. Didapatkan tingkat kelahiran prematur spontan $<34$ minggu adalah sebesar $1,03 \%$ ( $=$ 13) dan $2,34 \%(\mathrm{n}=30)$ pada kelompok aspirin dan plasebo dosis rendah (masing-masing OR $0,43,95 \%$ CI 0,26-0,84). Selain itu, tingkat kelahiran prematur spontan $<37$ minggu adalah 6,58\% ( $\mathrm{n}=83)$ pada kelompok aspirin dosis rendah dan 7,03\% $(\mathrm{n}=90)$ pada kelompok plasebo (OR 0,97; 95\% CI 0,71-1,33), dan tingkat kelahiran prematur secara keseluruhan $<37$ minggu adalah 7,84\% $(\mathrm{n}=99)$ pada kelompok aspirin dosis rendah dan $8,2 \%(n=105)$ pada kelompok plasebo (OR 0,97; 95\% CI 0,72-1,31). Setelah penyesuaian untuk variabel yang secara klinis relevan atau signifikan secara statistik, termasuk indeks massa tubuh, ras, penggunaan tembakau, status perkawinan, dan tingkat pendidikan, terdapat penurunan signifikan pada kelahiran prematur spontan $<34$ minggu pada kelompok aspirin dosis rendah (OR, 0,46; 95\% CI 0,23-0,89). Tingkat kelahiran prematur keseluruhan <34 dan <37 minggu dan kelahiran prematur spontan <37 minggu adalah 
serupa pada wanita yang menerima aspirin dosis rendah dibandingkan dengan plasebo. (Andrikopoulou et al., 2018).

Dalam penelitian lain oleh Moore et al (2014), aspirin dikaitkan dengan tingkat preeklamsia onset lambat $(\geqslant 34 \mathrm{w}$ ) yang secara signifikan berkurang dengan penggunaan aspirin $(\mathrm{P}=0,047)$, dengan penurunan sebesar $41 \%$ pada wanita dengan hipertensi kronis $(\mathrm{P}=0,041)$. Pada wanita dengan riwayat preeklamsia di kehamilan sebelumnya, risiko kecil untuk usia kehamilan (small for gestational age/ SGA) neonatus adalah 60\% lebih rendah dengan aspirin dosis rendah, meskipun perbedaan ini tidak bermakna $(P=0,086)$ (Moore et al., 2015). Sementara itu, pada penelitian Villa et al, didapatkan bahwa aspirin dosis rendah tidak mengurangi angka pre-eklamsia (risiko relatif [RR] 0,7; 95\% CI 0,31,7); hipertensi gestasional (RR 1,6, 95\% CI 0,6-4,2); pre-eklamsia onset dini (didiagnosis $<34+0$ minggu kehamilan) (RR 0,2, 95\% CI 0,03-2,1); atau pre-eklamsia berat (RR 0,4, 95\% CI 0,1-1,3); dan hasilnya tidak signifikan secara statistik dalam analisis terapi. Namun, dalam meta-analisis tersebut disarankan bahwa aspirin dosis rendah yang dimulai sebelum 16 minggu kehamilan untuk mengurangi risiko pre-eklampsia (RR 0,6; 95\% CI 0,4-0,8) dan pra-eklamsia berat (RR 0,3; 95\% CI 0,1-0,7) (Villa et al., 2013).

Nama kimia aspirin adalah asam asetilsalisilat (ASA) yang merupakan obat antiinflamasi nonsteroid (NSAID). Biasanya aspirin digunakan dalam dua rejimen dosis, yaitu dosis tinggi (600 mg) dan dosis rendah (60-150 mg). Obat ini memiliki efek anti-inflamasi, analgesik, antipiretik dan antiplatelet. Disfungsi endotel pada preeklamsia melibatkan peningkatan peroksidasi lipid, yang mengaktifkan COX dan menghambat sintase prostasiklin, sehingga menyebabkan ketidakseimbangan yang cepat dalam rasio TXA2 / prostasiklin (PGI2) yang mendukung TXA2. TXA2 mendukung vasokonstriksi sistemik, dan meningkatkan agregasi dan adhesi platelet, yang dikompensasi dalam konteks ini oleh efek vasodilator prostasiklin, yang kadarnya menurun tajam. Ketidakseimbangan ini terjadi sejak usia kehamilan 13 minggu pada pasien preeklamsia risiko tinggi (Dutta et al., 2019). Pengobatan aspirin dosis rendah selama 2 minggu dapat membalikkan ketidakseimbangan TXA2 / PGI2 dengan menghambat produksi THXA2 (Perneby et al., 2011). Beberapa penelitian mengamati bahwa aspirin dapat mengurangi pelepasan soluble fms-like tyrosine kinase-1 (sFLT-1) dari sel trofoblas dan menginduksi produksi faktor pertumbuhan endotel vaskular sehingga mendorong angiogenesis (Panagodage et al., 2016). LDA juga memodulasi produksi sitokin, mengurangi apoptosis dan mengubah agregasi dan fusi sel sehingga memperbaiki implantasi trofoblas yang rusak (Li et al., 2015).

Patofisiologi preeklamsia juga melibatkan ekspresi genetik faktor transkripsi STOX1 oleh trofoblas ekstravili yang memodulasi proliferasi trofoblas. Gen STOX1 diekspresikan secara berlebihan pada trofoblas ekstravili plasenta manusia dan dikaitkan dengan patogenesis preeklamsia (Dutta et al., 2019). Founds et al. menunjukkan dalam analisis transkriptomik, bahwa STOX1 diekspresikan secara berlebihan selama trimester pertama kehamilan yang memiliki hasil preeklamsia (Founds et al., 2009). Penelitian lain juga telah melakukan uji fungsional untuk menentukan fungsi gen STOX1 menggunakan model tikus invivo, diketahui penemuan gen ini menyebabkan hipertensi gestasional yang parah, proteinuria, peningkatan tingkat faktor antiangiogenik peredaran darah dan perubahan histologis di ginjal serta plasenta (Erlandsson et al., 2019). Aspirin dosis rendah berperan meningkatkan migrasi trofoblas ekstravili (extravillous trophoblast/ EVT) dan invasi ke arteri spiralis ibu yang mengurangi apoptosis sel plasenta. Preeklamsia juga dikaitkan dengan beberapa penanda anti-angiogenik, oksidatif dan pro-inflamasi yang diperbesar, serta peningkatan adhesi sel endotelial polimorfonuklear (PMN). Aspirin dosis rendah mengurangi tingkat peredaran darah dari faktor-faktor ini dan meningkatkan profil 
sitokin. Aspirin dosis rendah juga menyebabkan retardasi pada adhesi dan interaksi sel leukosit-endotel dan dengan demikian mencegah disfungsi sel endotel pada preeklamsia (Costa et al., 2013; Gil-Villa et al., 2012). Beberapa penanda biologis dapat diidentifikasi dalam darah ibu untuk dipantau sehingga dapat menilai tanggapan pengobatan setelah memulai pengobatan aspirin dosis rendah pada wanita hamil yang berisiko tinggi mengalami preeklamsia antara lain faktor pertumbuhan plasenta, protein plasenta 13, alfa fetoprotein (Dutta et al., 2019).

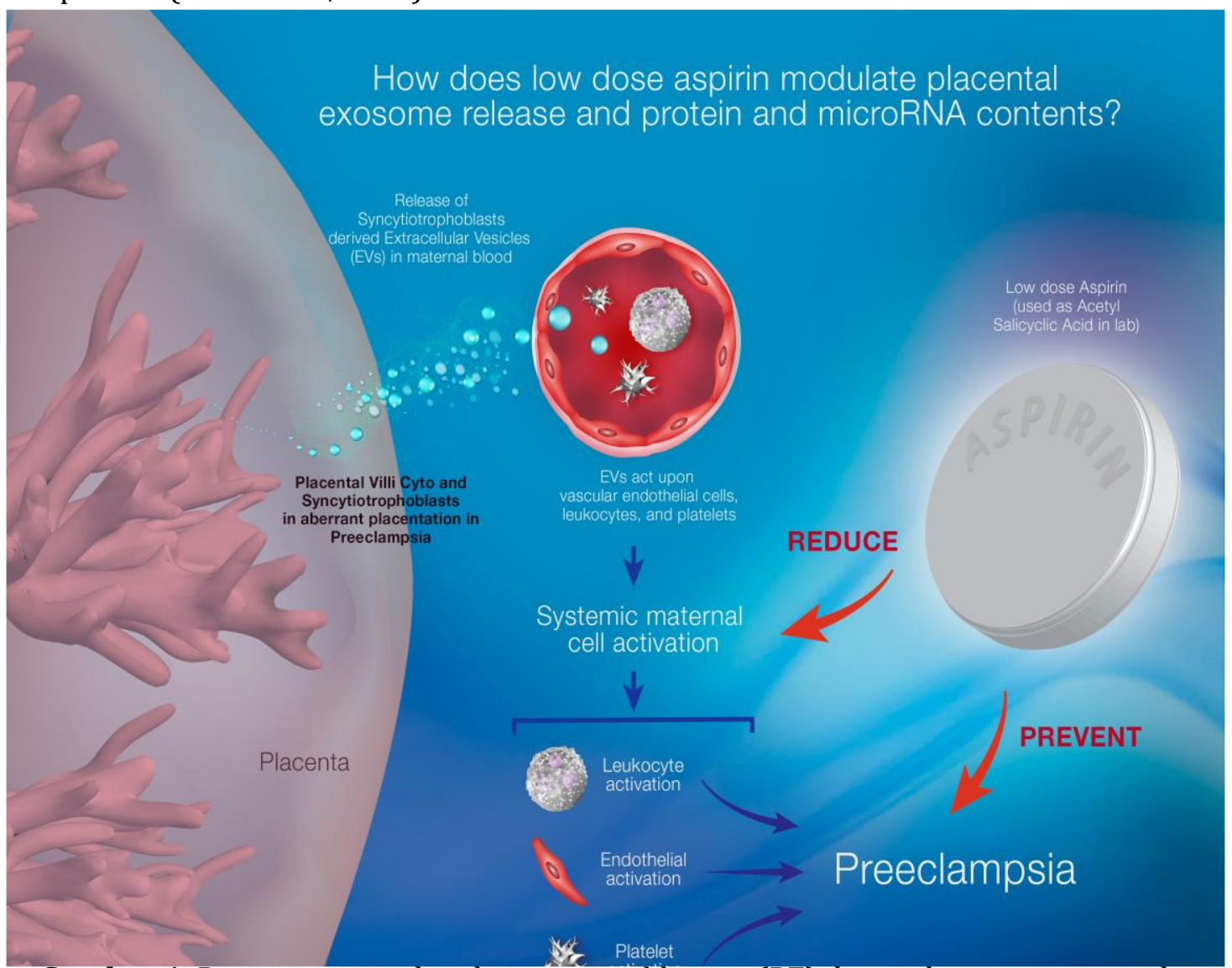

Gambar 1. Patogenesis perkembangan preeklamsia (PE) dan mekanisme pencegahan dengan aspirin dosis rendah (Dutta et al., 2019).

Mekanisme kerja aspirin melibatkan serangkaian proses. Aspirin mengasetilasi enzim platelet cyclooxygenase (COX) secara permanen, memodifikasi produksi prostaglandin yang berbeda dan juga bertindak sebagai agen analgesik, anti-inflamasi. Terdapat tiga isoform enzim COX yang dapat digunakan aspirin, dengan sumber terutama enzim ini adalah di trombosit, tetapi juga ditemukan di sel kekebalan lain seperti leukosit, monosit, dan makrofag. Aspirin menghambat COX-1 secara permanen dan COX-2 secara reversibel pada tingkat yang lebih rendah. Penghambatan yang dihasilkan dari pembentukan tromboksan A2 yang bergantung pada COX mencegah agregasi platelet. Efek ini dipertahankan untuk seluruh umur platelet selama 8-9 hari (Navaratnam et al., 2016). Dalam uji coba besar, acak, terkontrol plasebo pada wanita dengan riwayat keguguran, aspirin dosis rendah yang dimulai sebelum konsepsi dikaitkan dengan insiden bahaya komplikasi yang rendah. Meskipun jarang tetapi hasil kesehatan yang merugikan serius akibat aspirin dosis rendah tidak dapat sepenuhnya dikesampingkan. Aspirin dosis rendah prakonsepsi dapat ditoleransi dengan baik oleh wanita yang mencoba hamil, wanita hamil, 
serta oleh janin dan neonatus. Efek samping pada wanita dan janin atau neonatus serupa antara kelompok aspirin dosis rendah dan kelompok pengobatan plasebo dengan pengecualian perdarahan vagina yang tidak biasa atau berlebihan berdasarkan catatan medis ( $22 \%$ aspirin dosis rendah, $17 \%$ plasebo). Namun, angka kelahiran hidup yang lebih tinggi dan kelahiran prematur yang lebih rendah dengan pengobatan aspirin dosis rendah pada wanita menunjukkan keamanan aspirin dosis rendah yang masih meyakinkan (Ahrens et al., 2016).

\section{Simpulan Dan Saran}

Preeklamsia merupakan penyebab utama morbiditas dan mortalitas ibu dan bayi, namun algoritma skrining yang efektif untuk identifikasi wanita yang berisiko mengalami preeklamsia masih belum ada. Pengobatan dengan aspirin dosis rendah pada wanita dengan risiko tinggi untuk preeklamsia menghasilkan insiden perkembangan preeklamsia, kelahiran prematur dan kelahiran bayi kecil untuk usia kehamilan (small for gestational age) yang lebih rendah dari dibandingkan dengan plasebo.

\section{Daftar Rujukan}

Ahrens, K. A., Silver, R. M., Mumford, S. L., Sjaarda, L. A., Perkins, N. J., Wactawski-Wende, J., Galai, N., Townsend, J. M., Lynch, A. M., Lesher, L. L., Faraggi, D., Zarek, S., \& Schisterman, E. F. (2016). Complications and safety of preconception low-dose aspirin among women with prior pregnancy losses. Obstetrics and Gynecology, 127(4), 689-698. https://doi.org/10.1097/AOG.0000000000001301

Amaral, L. M., Wallace, K., Owens, M., \& LaMarca, B. (2017). Pathophysiology and Current Clinical Management of Preeclampsia. Current Hypertension Reports, 19(8), 19-21. https://doi.org/10.1007/s11906-017-0757-7

Andrikopoulou, M., Purisch, S. E., Handal-Orefice, R., \& Gyamfi-Bannerman, C. (2018). Lowdose aspirin is associated with reduced spontaneous preterm birth in nulliparous women. American Journal of Obstetrics and Gynecology, 219(4), 399.e1-399.e6. https://doi.org/10.1016/j.ajog.2018.06.011

Anto, E. O., Owiredu, W. K. B. A., Sakyi, S. A., Turpin, C. A., Ephraim, R. K. D., Fondjo, L. A., Obirikorang, C., Adua, E., \& Acheampong, E. (2018). Adverse pregnancy outcomes and imbalance in angiogenic growth mediators and oxidative stress biomarkers is associated with advanced maternal age births: A prospective cohort study in Ghana. PLOS ONE, 13(7), 1-12. https://doi.org/10.1371/journal.pone.0200581

Costa, F., Panaodage, S., \& Brennecke, S. (2013). Low dose aspirin improve trophoblastic function in early-onset pre-eclampsia. Ultrasound in Obstetrics \& Gynecology, 42(Suppl.1), 1-47.

Dixon, C. L., Marrs, C., Costantine, M. M., Pacheco, L. D., Saade, G. R., \& Chiossi, G. (2017). Effect of Low-Dose Aspirin on the Time of Onset of Preeclampsia and Time of Delivery. American Journal of Perinatology, 34(12), 1219-1226. https://doi.org/10.1055/s-0037-1602421

Dutta, S., Kumar, S., Hyett, J., \& Salomon, C. (2019). Molecular targets of aspirin and prevention of preeclampsia and their potential association with circulating extracellular vesicles during pregnancy. International Journal of Molecular Sciences, 20(18). https://doi.org/10.3390/ijms20184370

Erlandsson, L., Ducat, A., Castille, J., Zia, I., Kalapotharakos, G., Hedström, E., Vilotte, J. L., Vaiman, D., \& Hansson, S. R. (2019). Alpha-1 microglobulin as a potential therapeutic candidate for treatment of hypertension and oxidative stress in the STOX1 preeclampsia mouse model. Scientific Reports, 9(1), 1-13. https://doi.org/10.1038/s41598-019-44639-9 
Fantasia, H. C. (2018). Low-Dose Aspirin for the Prevention of Preeclampsia. Nursing for Women's Health, 22(1), 87-92. https://doi.org/10.1016/j.nwh.2017.12.002

Founds, S. A., Conley, Y. P., Lyons-Weiler, J. F., Jeyabalan, A., Allen Hogge, W., \& Conrad, K. P. (2009). Altered Global Gene Expression in First Trimester Placentas of Women Destined to Develop Preeclampsia. Placenta, 30(1), 15-24. https://doi.org/10.1016/j.placenta.2008.09.015

Gil-Villa, A. M., Norling, L. V., Serhan, C. N., Cordero, D., Rojas, M., \& Cadavid, A. (2012). Aspirin triggered-lipoxin A4 reduces the adhesion of human polymorphonuclear neutrophils to endothelial cells initiated by preeclamptic plasma. Prostaglandins Leukotrienes and Essential Fatty Acids, 87(4-5), 127-134. https://doi.org/10.1016/j.plefa.2012.08.003

Grotegut, C. A. (2016). Prevention of preeclampsia Find the latest version : Prevention of preeclampsia. The Journal of Clinical Investigation, 126(12), 4396-4398. https://doi.org/10.1172/JCI91300.As

Halscott, T. L., Ramsey, P. S., \& Reddy, U. M. (2014). First trimester screening cannot predict adverse outcomes yet. Prenatal Diagnosis, 34(7), 668-676. https://doi.org/10.1002/pd.4407

Khairunnisa, L. (2020). Dark Chocolate Consumption to Prevent Preeclampsia. Jurnal Ilmiah Kesehatan Sandi Husada, 11(1), 517-521. https://doi.org/10.35816/jiskh.v10i2.341

Li, C., Raikwar, N. S., Santillan, M. K., Santillan, D. A., \& Thomas, C. P. (2015). Aspirin inhibits expression of sFLT1 from human cytotrophoblasts induced by hypoxia, via cyclooxygenase 1. Placenta, 36(4), 446-453. https://doi.org/10.1016/j.placenta.2015.01.004

Mendes, S., Timóteo-Ferreira, F., Almeida, H., \& Silva, E. (2019). New insights into the process of placentation and the role of oxidative uterine microenvironment. Oxidative Medicine and Cellular Longevity, 2019. https://doi.org/10.1155/2019/9174521

Moore, G. S., Allshouse, A. A., Post, A. L., Galan, H. L., \& Heyborne, K. D. (2015). Early initiation of low-dose aspirin for reduction in preeclampsia risk in high-risk women: A secondary analysis of the MFMU High-Risk Aspirin Study. Journal of Perinatology, 35(5), 328-331. https://doi.org/10.1038/jp.2014.214

Navaratnam, K., Alfirevic, A., \& Alfirevic, Z. (2016). Low dose aspirin and pregnancy: how important is aspirin resistance? BJOG: An International Journal of Obstetrics and Gynaecology, 123(9), 1481-1487. https://doi.org/10.1111/1471-0528.13914

Odibo, A. O., Goetzinger, K. R., Odibo, L., \& Tuuli, M. G. (2015). Early prediction and aspirin for prevention of pre-eclampsia (EPAPP) study: A randomized controlled trial. Ultrasound in Obstetrics and Gynecology, 46(4), 414-418. https://doi.org/10.1002/uog.14889

Panagodage, S., Yong, H. E. J., Da Silva Costa, F., Borg, A. J., Kalionis, B., Brennecke, S. P., \& Murthi, P. (2016). Low-Dose Acetylsalicylic Acid Treatment Modulates the Production of Cytokines and Improves Trophoblast Function in an in Vitro Model of Early-Onset Preeclampsia. American Journal of Pathology, 186(12), 3217-3224. https://doi.org/10.1016/j.ajpath.2016.08.010

Perneby, C., Vahter, M., Åkesson, A., Bremme, K., \& Hjemdahl, P. (2011). Thromboxane metabolite excretion during pregnancy - Influence of preeclampsia and aspirin treatment. Thrombosis Research, 127(6), 605-606. https://doi.org/10.1016/j.thromres.2011.01.005

Rolnik, D. L., Wright, D., Poon, L. C., O'Gorman, N., Syngelaki, A., De Paco Matallana, C., Akolekar, R., Cicero, S., Janga, D., Singh, M., Molina, F. S., Persico, N., Jani, J. C., Plasencia, W., Papaioannou, G., Tenenbaum-Gavish, K., Meiri, H., Gizurarson, S., 
Maclagan, K., \& Nicolaides, K. H. (2017). Aspirin versus placebo in pregnancies at high risk for preterm preeclampsia. New England Journal of Medicine, 377(7), 613622. https://doi.org/10.1056/NEJMoa1704559

Villa, P. M., Kajantie, E., Räikkönen, K., Pesonen, A. K., Hämäläinen, E., Vainio, M., Taipale, P., \& Laivuori, H. (2013). Aspirin in the prevention of pre-eclampsia in high-risk women: A randomised placebo-controlled PREDO Trial and a meta-analysis of randomised trials. BJOG: An International Journal of Obstetrics and Gynaecology,20(1), 64-74.

https://doi.org/10.1111/j.1471-0528.2012.03493.x 